\title{
ARTICLE
}

\section{Adult reparation panels and offender-centric meso-communities: an answer to the conundrum}

\author{
Darren J. McStravick
}

\begin{abstract}
The community paradigm is continually cited as an important influence within restorative practices. However, this influence has not been sufficiently clarified. This article seeks to answer this conundrum by identifying a novel meso-community of care, concern and accountability that has been emerging as part of adult reparation panel procedures. This offender-centric community consists of traditionally secondary justice stakeholders led by criminal justice representative professionals including police officers and probation officials. It also includes lay volunteers and reparation programme officials dependent on state funding and cooperation. Professionalised panellists have led the development of surrogate familial bonds with offenders through the incorporation of a welfare ethos as part of case discourses. This care and concern approach has increased opportunities within case agreements for successful reintegration and rehabilitation. However, this article also acknowledges some concerns within panel processes in that, by attempting to increase accountability for harms caused, there is a danger that panellists are blurring the restorative lines between rehabilitation and genuine restoration and reparation.
\end{abstract}

Keywords: adult reparation panels, meso-community of care, concern and accountability, reintegration, restoration, surrogate familial bonds.

\section{Introduction}

The ideal of community and the importance of communitarian values are one of the most quoted principles within restorative justice literature. However, many restorative advocates have noted difficulties in clearly and concisely defining the concept and the true nature of its practical and theoretical role within restorative justice practices (Petrich, 2016; Rosenblatt, 2014; Rossner \& Bruce, 2016). Confu-

* Darren J. McStravick is a lecturer in Law, School of Law, Kingston University, Kingston upon Thames, UK. Contact author: D.mcstravick@kingston.ac.uk. 
sion over perceived roles and responsibilities inherent within this important concept has the potential to undermine and weaken underlying restorative values and the respective aims of restorative justice models generally, including the model under investigation for the purposes of this research study, the Irish adult reparation panel.

A series of semi-structured interviews and panel case study observations allowed for the identification of a newly emerging practical and theoretical 'mesocommunity of care, concern and accountability'. The reparation-based community emerged due to criminal justice professionals, panel facilitators and locally sourced volunteer members, traditionally secondary stakeholders within a restorative justice event, illustrating an emotional connection with participating offenders. This connection replicated the emotional bonds seen with more primary stakeholders such as close family members or friends within other restorative models. Panellists formed emotional relational bonds, in effect a surrogate support system, around each participating offender. This was achieved through a welfare-based approach to case discussions surrounding the offending behaviour which included a reintegrative and rehabilitative emphasis alongside a need to fully repair and recognise the harm caused by the offence to both victims and the offender themselves. The recognised surrogate support system represents an important development within the reparation panel model in that the offender reparation format does not allow for traditional primary stakeholders to attend case discussions and contract outcomes. This procedural lacuna introduces an element of concern for panel practices going forward. For example, a lack of victim involvement in reparation tasks opens up opportunities for a blurring of the restorative lines between rehabilitation and reparation. Despite this, state and community representative professionals, in partnership with lay volunteers, continue to successfully substitute these familial bonds as part of a newly developed community specific to each referred case and evolving around each participating offender.

\section{Restorative justice in Ireland: historical context}

Restorative principles have played a role within Irish justice systems for centuries. There were elements of social restoration within early Celtic law practice whilst the native Brehon law engaged with principles such as community ownership, negotiation, compensation and reparation (Leonard \& Kenny, 2011). The modern Irish criminal justice system has utilised the restorative justice concept within a number of formats. Within the youth justice system, juvenile services have been in operation since 1963 under the Juvenile Liaison Officer Scheme wherein diversionary cautions were allowed for in lieu of possible prosecution. More recently, Part 4 of the Children Act 2001 introduced the Garda Diversion Programme which has allowed for the implementation of restorative principles in the management of juvenile offenders such as diversion from prosecution when accepting responsibility, detention as a last resort and due regard given to the needs of victims. The 2001 Act, as amended by the Criminal Justice Act 2006, 
now includes the provision for any child who has committed criminal acts and accepts responsibility for that criminal behaviour to be considered for admission to a diversion programme which includes group conferencing, unless the interests of society are not be served by the diversion (Children Act 2001, Section 18).

Restorative justice in an adult context has not been as well defined in practice. Apart from the adult-based programmes which are the focus of this study, the only practical example of restorative justice for adults has been the Garda Adult Cautioning Scheme in operation since 2006. This Scheme allows for diversion from prosecution within a range of low-level offences if the victim is agreeable and it is seen as being in the public interest. Prior to this, the adult-specific offender reparation panel model emerged in part due to recommendations from a number of bodies charged with investigating the potential for a fundamental change within the Irish criminal justice system generally, and a change in the method by which adult offenders were being managed in particular (The National Crime Forum, 1998). From 1999 onwards, two pilot projects emerged on a nonstatutory, pilot-based footing charged with managing adult offending using a restorative justice approach which would combine offender reparation panels and victim/offender mediation with community involvement, an important principle throughout. ${ }^{1}$ The two adult-based restorative programmes are Restorative Justice Services (RJS) and Restorative Justice in the Community (RJC).

\section{Offender reparation panels and process}

Both reparation panel models are funded by the Probation Service and work in partnership with the judiciary and courts, the Irish police force (An Garda Síochána) and community agencies. RJS offers two restorative services, facilitated victim-offender mediation and offender reparation panels. RJC offers these services, plus a restorative conferencing option involving victim, offender and supporters of both. When the direct victim does not wish to participate, or when the crime is 'victimless', the reparation panel is the restorative option used. The reparation panel, across both programmes, was the only programme observed for the purposes of this research study. Cases are referred to both programmes by a judge at pre-sentence stage and after guilt has been established. Traditionally the programmes managed low-level offences and first-time offenders. However, as practice has developed, offenders with multiple convictions and higher tariff crimes such as assault and burglary are now being referred. ${ }^{2}$

The programmes utilise slightly different panel formats. The RJS model involves a facilitator, a police officer and Probation Service representative, and a community representative caseworker alongside the referred offender. The RJC panel comprises a facilitator, a police officer and one or two community representative volunteers along with the offender. Thus, there is no caseworker role as part of the RJC programme, whilst the RJS model does not include community-

1 Both programmes remain on a non-statutory footing as from December 2017.

2 For a further analysis of how one panel managed a serious offence, in this case an assault which resulted in a broken jaw, see McStravick (2015). 
based volunteers, with the caseworker representing that particular role. Probation Service officers represent key panel members within the RJS model but do not directly attend RJC programme meetings. Within the RJS model, probation officers are responsible for passing on referrals from court to the programme itself. They act as a conduit between the initial judge referral in court to contact with the programme and can also provide probation reports on referred offenders pre-panel in order to help determine their suitability for participation within the process. The RJC facilitator acts out these roles within that programme and is supported by a small administrative support team.

As part of the training to become a panel representative within both programmes, police officers and probation representatives sit in on a number of panel discussions as observers only, listen to the dialogue and watch how the process unfolds from initial introductions to contract formation. The facilitator role was carried out by the managers of both programmes within the majority of cases observed. They introduced the panel members to the participating offender at the beginning of cases and outlined the principles and aims of the reparation process. They acted as a 'reparative referee', guarding against domination of the process by any one panellist and also drafted the reparative contract as the meeting unfolded.

The RJS-based community representative case workers are recruited by way of a nationwide-based online advertisement. They are not legally trained 'conventional' lawyers, rather community members recruited and trained in legal and restorative justice principles. As regards the amount of training required, one caseworker stated that she had undergone three weeks of observing panels, seeing approximately fifteen cases within that time frame. Caseworkers act as a conduit between the programme and the courts, solicitors and other stakeholders. The role involves preparing the referred offender for the reparation process at pre-panel meetings and offering advice and support throughout the process whilst also engaging with rehabilitative organisations as part of the finalised contract agreement. There is also a support caseworker within RJS who does not sit in on panel meetings but provides administrative support. At the time of the research, the RJS model had one full-time panel caseworker (paid an annual salary), one part-time support caseworker and nine part-time panel caseworkers (paid on a case-by-case basis).

The RJC-based volunteer lay panellists are sourced from the geographical area with the positions advertised in local media outlets. They are required to attend training sessions on restorative practice and reparation panel practice specifically. During the interview, one volunteer explained how he was recruited alongside eleven fellow volunteer representatives and attended two practice sessions, each lasting approximately three hours. The sessions were managed by the RJC manager and facilitator. Recruits were taught the basic principles and history of the restorative justice concept both locally and worldwide. Volunteers were also required to participate in a mock panel where an imaginary case was roleplayed and possible scenarios teased out. The two sessions took place over a twomonth period and those volunteers interviewed thought that it was a good grounding for 'live' panel participation. 
The reparation process is similar across both programmes. Panellists sit around a table with the participating offender and discuss the crime and the harm caused by the offence. Within case discussions, principles such as reparation, accountability, rehabilitation and the successful reintegration back into the offender's respective communities are explored. The court remains the final arbiter as to the ultimate sanction and cases are adjourned until a contract agreement, drawn up between the panel members and agreed with the offender, is finalised and ultimately completed. Reparation agreements typically include an offender paying financial reparation to a recognised victim or charity, and paying symbolic or 'moral' reparation through acts such as community service tasks (Duff, 2003; Retzinger \& Scheff, 1996), writing a journal outlining the harm caused to direct and indirect victims, and letters of apology. An agreement not to reoffend in the future also forms part of contract terms, although this simply represents a promise by the offender and has no legal significance. Unlike the process in other conferencing programmes, there is no formal script stressing nonintervention of facilitators (Rossner \& Bruce, 2016: 116). Reparative facilitators will use a number of formulaic questions and develop the discourse from there. The reparative tasks listed help to illustrate to panellists and the wider community 'a moral rightness that reinforces the verbal undertakings made and accepted' (Strang, 2004: 102). If a victim wishes to indirectly participate in proceedings then a 'shuttle mediation' can take place wherein a letter is read out to the panellists and the offender during the case discussion. On occasion, meetings are also initiated with victim support groups and offenders for a 'surrogate victim' faceto-face encounter. A direct victim-offender face-to-face encounter is possible within the actual reparation panel model but is the exception rather than the norm.

Such reparations then can be seen as both financial and symbolic. This is important in that many victims participating in restorative schemes regularly tend to see emotional redress, for example in the offering of an apology, as more important than financial and material restoration (O'Mahony and Doak, 2006; Strang, 2001; Strang, 2004: 96). Both programmes manage a second panel meeting to confirm that the contract has been successfully completed. The case is then signed off and returned to the judge for a sentencing decision. If the judge believes the restorative aims and reparative actions have been successfully completed, the participant can be diverted from a formal criminal record. This outcome is not guaranteed, however, with sanctions sometimes handed down despite an offender successfully completing the reparation contract terms. Presiding judges, however, tend to look favourably on participating offenders whose actions signify elements of remorse, apology, reparation and accountability for any harm caused. ${ }^{3}$ Sentencing options can include a suspended sentence, fine,

3 Panellists remarked through informal conversations at the beginning and end of panel cases that referring judges would usually look favourably on offenders who successfully completed their contract agreements, even with more serious cases such as assault causing harm. 
community sentence or the case can be 'struck out' of court with no conviction being recorded. ${ }^{4}$

\section{Ethical considerations and methodology}

Ethical clearance was initially granted for observation of Irish adult reparation panel practices in 2012 by Dublin City University. After meeting with panel providers and explaining the research plans in detail, access was then provided. Verbal consent from participating offenders was obtained by panel facilitators before observations commenced. One of the chief aims throughout the observation process was to allow for as little intrusion as possible; thus, the researcher sat in the corner of the room and did not participate in case discussions and outcomes. Shorthand notes were allowed to be compiled within case meetings which were written up in full after each case.

The research methodology drew on an 'across method' triangulated research design (Denzin, 1989: 244) involving a desktop literature review, participant observations of both Irish reparation panel schemes and a series of semi-structured interviews with key stakeholders within the reparation process. It is argued that this semi-structured interviewing method, allied with participant observations, can 'each complement the other and increase data output whilst also enabling a better understanding of the subject at hand whilst overcoming their unique deficiencies' (Denzin \& Lincoln, 1998: 56). For Atkinson and Coffey (2002: 801), qualitative forms of triangulation can increase the respective strengths of observation and interview-based methods whilst also counteracting the potential limitations of both. This combination of observation and interview methodology techniques allowed for a greater understanding from the perspective of those professional and community representatives who actually participate and have a stake in the panel process (Rubin \& Rubin, 2012). In all, I observed 45 RJS panel-based case studies and 6 RJC panel-based case studies. Ten semi-structured interviews were carried out in total. It is acknowledged that this represents a relatively small interview sample. However, it included a wide range of key stakeholders within the reparation panel process. Interviews were carried out with two volunteer community representatives (RJC), two An Garda Síochána officers (RJC and RJS participants), the programme managers from both RJS and RJC programmes, two community representative caseworkers (RJS) and two Irish Probation Service panel representatives of the RJS model. Interview questions were designed to uncover key themes around restorative justice and community involvement. Professionals were asked about their knowledge of restorative justice practices, their backgrounds, level of training in the process and recommendations for improving the programmes. Community repre-

4 This provision is allowed for under S.1.1 of the Probation of Offenders Act 1907. Previous case outcome statistics from a Probation Service pilot study illustrated that 45 cases from an annual total of 168 managed by RJS resulted in additional sanctions with 19 of those referred back to the Probation Service for further intervention. RJC managed a total of 58 cases, all of which were 'struck out' if contracts were successfully completed (Probation Service, (2012). 
sentatives were asked about their backgrounds, reasons for becoming involved in the restorative process, knowledge of restorative principles and level of training in the reparation process.

A review of the literature was conducted before the field research began. The aim was initially to examine the practices and restorative principles evolving within a 'closed door' diversionary justice model. Initial data analysed the restorative quality of both programmes by way of a series of case studies examining the format of panel meetings and discourse employed within, participant backgrounds, the emotional and interactional dynamics occurring within case discussions, the crimes managed and contract terms issued. The aim was to uncover hypotheses as they arose within the data. As observations continued, it became clear that the concept of community was an increasingly utilised principle within panel discourses. This additional research theme was investigated as part of an ongoing literature review and the reparation panel data was then further analysed from a theoretical and practical 'communitarian' starting point. This allowed for a greater understanding of the principle and helped answer the question as to whether continuing claims by both programmes of the fundamental significance of the community ideal within reparation panel procedures are supported in practice.

\section{Defining community and its role within restorative practice}

As noted previously, practical and theoretical discussions surrounding the definition of community and its particular role within restorative justice practices are a common theme within criminal justice literature (Bazemore, 2005; Bazemore \& Stinchcomb, 2004; Gerkin, 2012; Olsen \& Dzur, 2004; O’Mahony \& Doak, 2006). Indeed, McCold (2004) contends that these definitional struggles represent one of the greatest challenges facing the ever-maturing restorative justice paradigm. Whilst many theorists and restorative advocates generally agree on the theoretical importance of community, they also note an element of confusion as to its concise make-up and parameters (McCold \& Wachtel, 2003; Walgrave, 2002). For Verity and King (2008: 473), such definitions within restorative literature problematically centre around a 'narrow and simplistic' identity and it is suggested that 'there is much that restorative practitioners could gain from engaging with both long standing and more recent debates within community development, about the contested nature of community and participation'. In this regard, Woolford (2009: 109) suggests that 'restorativists must be extremely careful in the image of community life they construct when constructing their programmes' and that inherent appeals at idealising the concept as community centred might well result in 'strict social and spatial boundaries' being drawn around such 'centred restorative communities'. Whilst it is easy to agree with Woolford's assertion that 'restorative justice must work with a notion of community that is open, multiple and flexible', it is also the case that a lack of specificity could result in empty promises and idealised jargon within which the promise of restorative justice and restorative principles such as reintegration, rehabilitation, accountability and 
reparation can become diluted to the point of becoming meaningless (Woolford, 2009: 109).

Throughout such discussions, the community concept is regularly portrayed as an important element within a successful restorative justice process (McCold, 2004; Rodriguez, 2005; Walgrave, 2002). Indeed, as Walgrave (2002: 71) argues, it can be seen to occupy a 'central position' within restorative ideology generally. In addition, the level of community involvement is said to represent one of the most important differences between the retributive justice and restorative justice paradigms (Dhami \& Joy, 2007). Community can also take on a number of personas. It has been described as a geographical area, a 'community of place' (McCold \& Wachtel, 1998), an area wherein 'people know and care for one another' (Etzioni, 1994: 31; Etzioni, 1995), as well as a set of values and relational bonds. Such bonds can result in a series of 'meaningful interrelationships ... and common interest in something greater than ourselves' (McCold \& Wachtel, 2003: 295).

Community can also adapt to a number of roles. For example, within a group conferencing restorative model, it can be 'an extension of both offender and victim' wherein family members and friends of both stakeholders can come together around the conferencing table and attempt to repair any harm that has been caused; it can be another stakeholder, along with the victim and offender, a 'secondary victim which has suffered its own harm through social unrest or threat'; and it can represent the potential, idealistic goal of a successful process, 'an ideal form of collective life' in which a repentant offender can be successfully reintegrated and rehabilitated amongst fellow ideal community members (Walgrave, 2002: 75). Indeed, the inclusion of community members as an extension of victim and offender has been viewed as the vital ingredient which can transform a partial restorative justice model into one that can be legitimately called fully restorative (McCold, 2000). In this way, the support network of family members and friends can act as primary stakeholders. They, along with the victim and offender, become the most important actors within a restorative process as they are the most affected by a particular crime and have the greatest emotional connection. This grouping can include parents, spouses, family and friends, as well as teachers or co-workers. Thus the community concept begins to resemble a relational 'micro-community' at play within the restorative paradigm (McCold, 2004: 155). This 'micro-community' or 'individual community of care' is said to form a circle of support within the life circle of those victims and offenders who have been directly affected by a particular crime. These primary stakeholders 'provide the personal, emotional and material care and support we need to face problems and make difficult decisions in our lives'. It represents 'a network of relationships, [and] is not dependent on geography' (McCold, 2004: 156). From this 'micro' per- 
spective then, the harm from a criminal justice act is 'specific' to those relationships most deeply affected by the criminal behaviour (Braithwaite \& Daly, 1995). ${ }^{5}$

For McCold, such primary stakeholders, or 'micro-community' members, can be contrasted with 'secondary stakeholders', or 'macro-community' members. This particular community can include neighbours and those 'who belong to educational, religious, social or business organisations and whose area of responsibility or participation includes the place or people affected by the incident' (McCold, 2004: 158). In this regard, government officials and criminal justice professionals can also be viewed as 'secondary stakeholders'. Such 'secondary justice stakeholders' have been said to lack the emotional connectivity of their more personal, relational counterparts, and are judged to be more concerned with aggregate rather than specific harm, their primary aims being the results of the restorative process and the 'specific actions taken to repair the harm' rather than the actual process itself (McCold, 2004: 158). In contrast to McCold's relational theory of community, Umbreit, Coates and Vos (2004) argue that the very idea of close relational bonds within a collection of primary stakeholders enabling a 'community', be that 'micro' or otherwise, only results in stretching the concept to breaking point. The authors have taken issue with McCold's definition of a 'micro-community' and suggest that, 'to speak of the victim, the offender, their relatives, and their friends as community in the way [he] does not only is a stretch; it is inconsistent with the origins and intent of restorative justice. A more sensible term to describe such a collection of persons is 'social network' (Umbreit, Coates \& Vos, 2004: 85).

\subsection{The hybrid meso-community: a reimagining of McCold's communities}

The reparation styled meso-community concept has been moulded on a number of elements within both the 'micro' and 'macro' community theories put forward (McCold, 2004). However, the reparation community identified as part of this research study fundamentally contrasts with this version in that, first and foremost, it is the panel members themselves rather than close familial support structures that were predominantly building this welfare ethos. In effect, the community identified within the reparation panel process represented a relational 'macrocommunity' delivering the emotional support structures more prevalent within McCold's familial 'micro-community' (McCold, 2004). That is to say, theoretically thinner relational bonds between the offender and criminal justice professionals, programme members and local volunteers came to represent, in reality, the thicker bonds more expected between family members and close friends of victims and offenders within a restorative meeting. Bottoms argues that the 'social mechanisms of restorative justice' depend on 'adequate meso-social structures [existing] to support restorative justice-type approaches' (Bottoms, 2003: 79; Daly, 2006), whilst Daly has also broken down the significance of these particular structures, noting that they refer to

5 This identified 'community of care' has been further elaborated on by Braithwaite and Daly in relation to restorative family group conference participants. They have included a 'community of concern' concept, again consisting of close family members, friends and extended family of primary stakeholders within a particular criminal event. 
ordered sets of relationships that are part of pre-modern societies (for example, residence, kinship, or lineage). These relationships embed elements of 'intra-societal power' and coercion, which make dispute settlement possible. A second feature of relationships in pre-modern societies is that disputants are 'part of the same moral/social community'. They live in close proximity to one another or are related to one another, and typically wish to continue living in the community. These meso-social structures and 'thick' social ties, which are commonly associated with pre-modern societies, are not present in modern urban contemporary societies (Daly, 2006: 137).

Within reparation case deliberations the panel members have themselves demonstrated a surrogate version of these general 'meso-social structures and thick social ties' specific to each participating offender and panel case. Indeed, such bonds can help engineer and bridge 'social capital' and represent an important and valuable element in the successful imaging of communitarian ideals in that they can 'affect the productivity of individuals and groups ... social capital refers to connections amongst individuals, social networks and the norms of reciprocity and trustworthiness that arise from them' (Putnam, 2000: 19).

Similar surrogate relational bonds have been identified previously in a prison setting amongst inmates, prison staff and volunteers involving restorative circle processes aimed at cognitive transformation (Petrich \& Morrison, 2015). They have also been identified as part of an Australian conferencing model between community representative actors and victims and offenders (Rossner \& Bruce, 2016). However, the surrogate relational bonds observed as part of reparation panel case management contrast with these examples in that the bonds identified were primarily moulded by police and probation officers as well as reparation programme actors. This is all the more important due to the reparation panel format which does not procedurally allow family members or friends to participate around the restorative table. Panellists adopted this primary role in a number of ways. A welfare-based approach to the offending behaviour was encouraged that included rehabilitative and reintegrative options, as well as a focus on accountability for the harm caused by the offence. These panellists, alongside their community representative counterparts, discussed the participant's background, family, relational and personal issues and future plans during the introductory discussion stage. In doing so, panellists were managing the person as well as the criminal act itself. There were also, on occasion, sympathetic overtures to participants. Some of those attending had alcohol and drug dependency issues and it was noted within discussions that such dependencies meant that the participant themselves could be classed as an indirect victim in need of rehabilitative support and advice. This approach has aspects of the 'Good Lives Model' prisoner desistance and rehabilitation theory whereby offenders are assumed to be complex human beings, not simply risk managed objects, with the same goals and hopes of other community members (Ward \& Brown, 2004; Ward \& Maruna, 2007).

Panellists, then, represented a newly identified hybrid meso-community wherein traditional macro members imitated micro-community elements within restorative discourses through a care, concern and accountability approach to 
offending behaviour. They represented missing familial interests within case discussions and broadened the familial and communitarian structures within cases by adding apology letters to a wide range of indirect victims, such as family members and close friends of both victims and offenders. They increased these structures further by adding rehabilitative options within agreed contracts that have specifically linked local service suppliers with individual dependencies and social care concerns. Many of these options were discussed outside actual contract negotiations, thus representing more of a conversational, social well-being approach rather than a criminal justice sanction stipulation. In essence, reparation panel procedure has helped transform the conventional criminal justice professional role from 'service broker at best, and rule enforcer at worst' (Bazemore \& Erbe, 2004) into that of a genuine rehabilitative and reintegrative collaborator.

Furthermore, in line with Bottom's argument that 'thick' social ties can be somewhat limited in modern-day society, a number of those participating offenders being observed admitted to panellists that they had damaged and broken off their respective social ties and were unable to avail of family support structures. One participant admitted that his alcohol dependency had resulted in him moving out of the family home and losing all contact and access. One female offender was living in a homeless shelter with two small children due to a relationship break-up, whilst another female participant was acting as a guardian for her sister's two children whilst she served a prison sentence. Therefore, such surrogate relational meso-bonds within panel case deliberations provided the only available welfare-based support system for a number of these panel participants. Such panel-specific relational bonds are important in that crime can be primarily regarded as occurring within a 'relational justice' dynamic and should only secondarily be regarded as an offence against the state and its legal rules (Schluter, 2003). Further, Giordano, Schroeder \& Cernkovich (2007) argue that close personal relationships can help to improve the opportunities for desistance from crime as a result of an emotional support network that encourages a desire for self-improvement.

Moreover, it is novel that it is state representative professionals and statereliant programme facilitators that have been predominant in developing rather than diluting these offender-centric bonds. Cohen has previously cautioned against the true nature of the community-based ownership of justice ideal, arguing that criminal justice models appearing to promote community interests can alternatively serve to extend and strengthen government influence and power over such practices (Cohen, 1985). For others, past decades have seen a change in the objectives and priorities of criminal justice organisations and a reworking of management styles and practices wherein sentencing has changed from 'a discretionary art of individualised dispositions' to a 'rigid and mechanical application of penalty guidelines and mandatory sentences', whilst probation and parole agencies have

de-emphasised the social work ethos that used to dominate their work and instead present themselves as providers of inexpensive, community based 
punishments, orientated towards the monitoring of offenders and the management of risk (Garland, 2001: 18-19).

\subsection{The meso-community of care and concern}

Such concerns within reparative panels of an 'all pervasive managerialism' (Garland, 2001: 19) tainting restorative practices did not materialise within the case studies observed. Contrary to these fears, a reparation panel-based hybrid 'mesocommunity' emerged within the micro- and macro-community dynamic. It was moulded without the direct familial support structures more obvious within other restorative models such as family group conferencing and circle sentencing cases. Instead, the panellists illustrated a series of surrogate familial relational bonds around the participant, outlining the potential damage caused to the participant themselves as well as to the direct victims, the need to direct their thoughts and actions towards a non-recidivist future, and the need to focus on rehabilitative options. In addition, panellists would also congratulate the participant after a contract had been successfully completed during follow-up meetings, thank them for their efforts, and wish them well in the future. Phrases such as 'you have done well here ... you should be proud of yourself ... we realise that this was not easy for you' were a common ingredient of post contract discourses. Essentially, in evidence, here was a sense of redemption for past criminal behaviours which is rarely seen within the workings of the more conventional criminal justice process (Braithwaite \& Mugford, 1994; Maruna, 2001). The practice also represented a delabelling of the past criminal persona and an introduction to a potentially new narrative identity (Maruna \& Ramsden, 2004; McAdams \& McClean, 2013; Petrich, 2016). Rather than a discussion on the facts of the crime and its impact, as was the case within the initial panel meeting, the second panel meeting within the RJS reparative model allowed for a different narrative to emerge. Within this narrative, the participant could reflect with the panellists on the good work completed as part of the contract agreement, the successful community service task, the reparative sum paid to a charity or direct victim, the handwritten letters of apology explaining their actions and remorse, and the visits to community-based substance abuse services. This allows for the realisation of an explicit aim of restorative mediation, 'to help assist offending individuals in developing redemption scripts whereby they can prove to the victim and others impacted that they are more than the sum of their offences' (Maruna, 2016: 294). Furthermore, the participant now has acknowledgement for his good deeds which can then lead to 'an optimistic perception ... of personal control over one's destiny' and 'a desire to be productive and give something back to society' (Maruna, 2001: 88).

In terms of the welfare themed elements to panel deliberations, much of the groundwork for utilising this approach lay in the preliminary discourse between offender and panellists at the beginning of each panel meeting. The chairpersons within both programmes would begin case deliberations by asking the participants about their family life, relationships, employment history, general interests and future plans. Such discourse resembled a 'humanistic dialogue', treating participants as 'persons' in their own right rather than simply offenders to be sanc- 
tioned. This notion of a 'humanistic model of communication' as used by restorative facilitators, can be illustrated by dialogue that is not concerned with driving settlements; rather conversations and mutual aid are facilitated by building trust between parties whilst remaining neutral and by recognising the different strengths of participants and the power of silence (Umbreit, 1998).

Such dialogue served to visibly relax the participating offenders at the start of the process. Access was not granted by panel gatekeepers to interview this group of stakeholders. However, by observing the body language and demeanour of offenders during case discussions, it is submitted that this informal approach at the beginning of meetings of discussing a participant's background and interests did appear to put them at their ease. It also allowed participants to open up to the panellists about past convictions, mental health issues and relevant drug and alcohol dependencies. At the beginning of the process many participants initially appeared stressed and nervous when they entered the panel room. When discussions began, many of those observed sat in silence with their arms crossed, not making eye contact with other panellists. However, as the panel progressed, participants appeared to relax more, their answers became longer and more descriptive and at the end of the meeting participants would shake hands, smile and thank the panellists. This type of interaction has been viewed previously between significant others and serious offenders within restorative family conferences. Certain 'rituals' were observed wherein participants laughed and cried together, sat up straight after initially slouching, and shook hands and hugged at the end of the conference. It has been contended that this type of behaviour within a restorative meeting represents a vivid example of a shared morality, solidarity and an emotionally energetic experience (Rossner, 2011, 2013).

Within one RJS-based panel case, an 18-year-old female participant was asked how many brothers and sisters she had, and what schools she had attended. Through this line of questioning, the panel then discovered that she had left school at fifteen because she had been bullied. The chairperson also asked her to think about possible further education courses. The detailed introduction also included questions such as, "how do you relax ... do you have any hobbies ... are you presently in a relationship?' The participant described how much of her time was taken up looking after her younger brothers and sisters at home and that she had few friends with whom she associated. The participating offender argued that the offence occurred whenever her boyfriend gave her a set of knives as 'a present' for her parents. The Garda officers stopped and searched the girl and charged her with possession of the knives. The acting community representative caseworker stated to the girl that 'you are not a bad person'. She was told to 'stop feeling guilty' and that 'you need a friend'. The panellists reinforced the idea that because she was usually at home helping out other family members she had then little time for hobbies, friends or relaxation. They all agreed that this was not a healthy situation for a young girl.

Within the terms of the contract agreed for this particular case, a letter of apology to her own family members was included and the potential harm caused by the event was forcibly highlighted. However, this was combined with proposals for possible rehabilitation with a requirement to establish a connection with a 
local job centre to enquire about courses as well as a visit to the local community centre to check out the activities being arranged there. The participant was also required to write a plan for the future. This can represent a useful exercise for participating offenders in that it requires thought on possible educational and career opportunities and the means by which these life goals can be attained.

As part of this case discussion, the programme facilitator added further to the welfare ethos by explaining that he was one of eight children himself, but that a balance was needed between helping out with family duties and taking time for yourself. The preliminary discussion had also brought up issues with debts within the family home, issues unrelated to the crime being managed. The Garda representative asked if she was in a local credit union. All the panellists agreed that, instead of a reparative sum to a charity being included within the contract, the participant should lodge 50 euros with a local credit union. It was decided that another monetary reparation fine and the pressure that would bring for the girl and her family would be inappropriate on this occasion. Thus, within this particular case the care and concern elements within a welfare-based discourse were fully evidenced. This was the case even within the supposedly 'reparative' terms of the agreed contract. In effect, the offender was being asked to 'repair the harm to herself' by setting up a savings account that she could benefit from in the future.

Community representative and criminal justice professional panellists working together in this way represent a 'democratic professionalism approach to offender management' (Olson \& Dzur, 2004). Such an approach can address the apparent conundrum within the restorative justice concept, and within reparation panels specifically, wherein 'restorative justice theory leaves virtually no role for professionals, yet in practice they are deeply involved in restorative justice programmes' (Olson \& Dzur, 2004: 139). For Olson and Dzur, criminal justice professionals should ideally act as 'social trustees' in that 'professionals have social responsibilities in addition to their fiduciary and function-specific obligations to their base of clients', and that such professional expertise should be ideally directed towards 'facilitating public participation and control ... they do not inevitably reduce the sphere of lay or citizen involvement, but share decisionmaking domains rather than monopolizing them' (2004: 147). Their role is one of task sharing, of finding a middle ground between overly technocratic professionalism and parochial communitarianism so they can successfully 'rebalance competing values of rule following versus holistic engagement and of fairness to individuals versus responsiveness to community' (Olson \& Dzur, 2004: 171).

A further analysis of additional case data illustrates this care and concern approach, within a 'democratic professionalised' context, further. An RJS managed case involved the theft of over 800 euros worth of clothes. The participant was an estranged mother with two children living in temporary accommodation who had been attending mental health services in a local centre. Discourse at the beginning of the meeting involved the programme facilitator asking

what is your accommodation like, it cannot be easy living with a small family in these circumstances ... how are the children coping ... how do you get the kids to school? 
The caseworker also illustrated a willingness to become actively involved in the case discussion by persuading the other panellists to reduce the reparative financial sum as part of the contract terms from 50 euros down to 40 euros stating that 'it needs to be affordable'. Contract terms included a visit to a local debt managing service as well as a meeting with housing officials to attempt to address the accommodation issue.

Such active community representative involvement is important in that it lends a general sense of legitimacy to what is in essence an extension of a courtcontrolled and state funding-reliant criminal justice process (Rossner \& Bruce, 2016: 109) and contrasts with a lack of active responsibility by lay volunteers within other programmes (Rosenblatt, 2015: 121). Such discourse, alongside reparative options such as anger management, debt control and educational courses, can at least begin to address the concerns put forward by Levrant, Cullen, Fulton and Wozniak (1999) wherein restorative conferences continually promise to make wide-ranging changes to offender behaviour without addressing the fundamental dilemma of how to alter the daily living conditions which were conducive to the initial offence. Moreover, many of these rehabilitative social care and welfare-based concerns were discussed outside the parameters of the reparation contract itself and represented the cornerstone of this newly identified hybrid 'mesocommunity of care, concern and accountability'. This welfare themed discourse contrasts fundamentally with the adversarial dynamic within a courtroom justice encounter wherein the personal narratives of both victims and offenders are often neglected (Doak, 2011). ${ }^{6}$ In this regard, these preliminary introductions were arguably a small but vivid example of how panel practices can begin to challenge the fundamentals of the conventional criminal justice process by increasing normative dialogue and emphasising 'right relationships over right rules' (Zehr, 1990: 211), thereby returning ownership of the criminal justice conflict back to the primary stakeholders most affected (Christie, 1981).

Such reparative-based discussions around contract formulation do, however, open up potential questions around the level of 'appropriate punishment' within contract agreements. For Christie (1981), punishments should inflict as little pain as possible as we should be striving for an alternative to conventional style punishments rather than alternative punishments. He has further argued that in addressing acts as crimes, emphasis should be put on solving conflicting interests between people. In a similar vein, Mika and Zehr talk of crime as 'fundamentally a violation of people and interpersonal relationships', with a priority on addressing the harm caused to those relationships between victim, offender and the wider community (2003: 143). Conversely, Duff suggests that 'restoration through retribution' should be the desired outcome of restorative processes; that truly understanding restoration within the context of criminal justice, and understanding what retribution stands for in the criminal punishment context, can then help to

6 Doak (2011) argues that the conventional trial process tends to 'crush' such narratives. It is acknowledged, however, that such a welfare ethos might prove more practical within the reparation process wherein guilt has already been proved or admitted. 
illuminate the fact that 'restoration is not only compatible with retribution and punishment but requires it' (2003: 382).

Reparative terms within contracts generally were discussed on an equal basis between all panel members and participating offenders before agreement was reached. Offenders were asked how they themselves thought they could repair the harm caused and were encouraged to put forward possible reparative outcomes. Such task sharing helps to ensure that the process remains fair to those offenders attending and can also help to nurture an improved notion of both citizen participation and legitimacy within practices (Duff, 2003). A degree of legitimacy is important on a number of levels. Firstly, it can help to delimit certain aspects of what Sherman (1993) has called the 'defiance theory'. Moreover, Tyler and Huo (1990) have previously contended that trust and legitimacy can prove key to improving compliance with the law. This assumes that when an offender views a sanction as illegitimate, when they have a weak relationship or no relationship at all, with the sanctioning agent and when they deny any element of shame attached to the offence, the result can see such offenders continue to break the law. Alternatively, future recidivist tendencies may be reduced if sanctions are viewed as fair and relational bonds are reattached to mainstream society (Rossner, 2011; Rossner \& Bruce, 2016). Sherman argues that restorative mediation and conference models are more likely to achieve these desistance patterns, whereas a court room-based justice model is more likely to illustrate defiance. In this regard, previous research within youth family group conferencing practices in New Zealand has further argued that reconviction rates can be decreased if offenders agree with the outcome, believe the process is fair and feel generally involved in the decision-making process (Morris \& Morris, 1999; Tyler, 1990).

Other case examples of the care and concern approach included a male offender with a large number of previous offences who had admitted to criminal damage and attempted car theft. The initial informal introductory questioning at the beginning of the meeting had uncovered alcohol dependency and occasional drug use problems relating to a car accident in the past. In this accident, which led to the participant serving a custodial sentence, the offender's friend had been killed as a result of his dangerous driving. With this information, the panellists were able to tailor the reparative contract towards alcohol and drug treatment and counselling courses within the local community. Whilst the panellists reinforced the victim suffering and the harm caused by the previous and present criminal acts, they also illustrated elements of sympathy for the participant and noted that he had also been harmed as a result of his friend's death. A further task within the contract involved writing a 'plan for the future' in order to help the participant with prolonged feelings of restlessness and boredom, further facts that emerged as part of the preliminary discourse. In other cases, participants have admitted to mental health problems including bipolar disorders and suicidal tendencies. This welfare approach allowed panellists to sympathetically discuss these health concerns and refer these participants to relevant medical support services within the local community. 


\subsection{The meso-community of accountability}

Alongside the relational meso-bonds between offender and panel members and the sense of welfare ethos as illustrated within case examples, reparation discourses also included an element of 'accountability' when striving to agree reparative contract terms. Participants were continually made aware of the harm caused by their offending behaviour, of the needs of direct victims as well as the potentially wide net of indirect victims within the local area, of the requirement to make amends for the crime in material and symbolic fashion, and of the necessity for taking responsibility and exploring their personal potential for a non-recidivist future. Within a number of cases participants argued memory loss and a lack of responsibility around the circumstances of the crime, as well as claims of their own victimhood. These claims of victimhood (Kenney \& Clairmont, 2009), and of neutralising the harm caused (Sykes \& Matza, 1957), ${ }^{7}$ such as being attacked by security guards when attempting to leave shops with stolen goods, were introduced into panel discussions despite contrary evidence within case notes. Within conferencing models in New South Wales, panellists, including community representatives, have similarly challenged offenders who denied responsibility (Rossner \& Bruce, 2016: 115). Irish-based panellists dismissed participants' attempts to limit accountability and bridged the reparative panel lacuna in familial, and indeed victim, participation by undertaking the role of the surrogate moral guardian and highlighting the harm caused to all stakeholders, including the offender themselves and local community members.

It is acknowledged at this point, however, that in attempting to increase the principle of accountability within case discussions, panellists need to tread carefully within restorative parameters and achieve the correct balance between rehabilitating the offender and successfully restoring and repairing the harm caused by the criminal act. This blurring of the lines between rehabilitation and reparation, and between 'responsibilisation' and restoration, is a common criticism of restorative justice practice and procedure (Gray, 2005; Rosenblatt, 2014; Willis, 2016). In UK prison-based programmes, for example, 'restorative' schemes were labelled as such even though the work carried out was confined to within prison walls without any form of victim input or redress (Wood \& Suzuki, 2016: 152) whilst Daly (2016: 11) has further argued that the very term 'restorative justice' is generally misunderstood and misconceived when the label is attached to any process resulting in a non-custodial sanction. Such blurring of restorative principles represents a particular problem for reparation panel practice. Of particular concern is the lack of direct victim participation and the embellishing of the victim persona, the development of a possible 'responsibilising' discourse by panellists, and the process of managing apologies within contracts.

7 Kenney and Clairmont (2009) argue that offenders can attempt to delimit their own illegal actions by adopting victim characteristics during restorative conferences. Sykes and Matza (1957: 666) have also argued that 'much delinquency is based on what is essentially an unrecognized extension of defences to crimes, in the form of justifications for deviance that are seen as valid by the delinquent but not by the legal system or society at large'. 


\section{Discussion and conclusion: accountability versus harm restoration}

In attempting to increase harm awareness and accountability, panellists regularly embellished the concept of victimhood within cases. In this regard, and returning to the discussion above surrounding the participant with 46 convictions who admitted to car theft, panellists told him that such offences affected the direct victim and the general local community; that what can result is inconvenience and financial problems for the victim and that such crimes can provoke feelings of fear and insecurity amongst the residents of that area. Panellists noted that the car, if successfully stolen, could have been driven into another family's car and someone else could have been seriously injured or killed. They extended the list of possible victims to the Garda officers themselves, with the Garda panellist explaining that it can be dangerous for arresting officers in pursuit of stolen vehicles.

This embellishing of the victim identity is a tool regularly used by reparation panellists in order to increase an understanding of the harm caused and alleviate concerns over a lack of direct victim participation within the process generally. However, increasing the 'victim' persona in such a way increases the potential for a moralising, retributive discourse to trump restorative principles of accountability and reparation. Panel members regularly introduced a series of indirect, theoretical victims into case discussions in order to reinforce the damage caused by the specific crime. In another series of cases concerning shop thefts, panellists argued that these offences can affect other community members as prices have to be raised to cover the costs of higher insurance premiums and this, in turn, results in local jobs being put at risk. Furthermore, an offender was told that his assault of a male in a local nightclub not only affected the direct victim but also onlookers frightened of revisiting the establishment or socialising in the local area due to an enhanced fear of crime. Panellists also reminded participants that police officers could also be classed as indirect victims of crime because of the possibility of injury and abuse to attending Garda officers. A Probation Service and Garda representative panellist both remarked that Garda officers were victims of assaults and that their jobs could be very stressful, and that such offending behaviour placed a burden on the Gardaí's capabilities of managing more serious offences to the detriment of other community members.

This type of panel discourse mirrors similar 'constructions' within Hoyle's Thames Valley restorative cautioning research in which facilitators were seen to create victims out of parents, members of an offender's family, police officers and others when the 'real' victim did not wish to be involved or when the crime was 'victimless', such as with a motoring, drugs or shop theft offence. This then led to facilitators exaggerating the extent of the harm caused by such low-level offending (Hoyle, 2002; Hoyle \& Rosenblatt, 2016). Just as reparation panel members discussed the broadening of the victim spectrum after minor shop thefts and public order offences, so restorative cautioning mediators within Hoyle's study spoke at length of 'institutional victims' such as a department store having to raise prices as a result of the crime (Hoyle \& Rosenblatt, 2016: 38). Such exaggerations may actually serve to decrease rather than increase any sense of accountability for 
participating offenders in that the mediation discourse becomes a moralising exercise wherein the offender 'turns off' and fails to take the process seriously (Hoyle \& Rosenblatt, 2016: 39). Rossner has also observed offenders and their supporters disengaging from the conferencing process whenever victim representatives, in place of direct victims, and community representatives spoke in general terms about crime, community harm and the fear of crime (Rossner \& Bruce, 2016: 117).

Moreover, Garda panellists were observed within a number of case studies speaking to participants in an adversarial manner rather than as part of a restorative discourse. For example, one police panellist gave short shrift to a participant's account that he did not intend to steal car wheels even though he was arrested with a wrench. Questions were put to the offender such as 'what then were you doing with the wheel brace if you did not initially intend to steal the wheels' and 'put yourself in our position ... would you believe this version of events?' The Garda panellist further highlighted the harm caused by the offending by explaining that the participant was well built and tall and would have frightened the potential victims and owners of the car. He asked the participant,

how do you think the householders felt when they saw such a large person approaching their property armed with a wheel brace in the dark? Do you think they would have been frightened?

It is arguable whether such questioning will result in accountability being fully realised or simply serve to further 'turn off' the participant from the process. Similar illegitimate police questioning was observed within restorative adult and juvenile cautioning procedures (Hoyle et al., 2002; Young \& Hoyle, 2003).

A lack of direct victims around the reparation table also delimits opportunities for the 'bridging of social capital' and potential for strengthening 'weak' connections between community members (Putnam, 2000: 19). Thus, the absence of a face-to-face meeting between offender and victim can limit opportunities for this 'bridging' to occur, especially important as these groups represent the primary stakeholders in any restorative justice-styled criminal event (McCold, 2004: 162). The importance of bridging social capital has been recently observed by Willis who argues that such face-to-face meetings between victim and offender, in this case as part of a Youth Conditional Caution, can lead to enhanced opportunities for offenders including increasing the potential for future employment prospects, identifying new positive skills and increasing the number of positive relationships within an offender's social spectrum (2016: 182). Conversely, when no direct victim participation occurred as part of the same participant's Youth Referral Order, there were no 'magical' moments of 'understanding', 'forgiveness' or 'empathy'. Furthermore, the volunteer representatives on the Referral Order panel did not represent the offender's local community nor was any 'relationship' seen to develop between that group and the offender (Rosenblatt, 2014; Willis, 2016: 184-185).

A further concern on the capability of reparation panels to successfully balance restorative and rehabilitative aims involved the managing of letters of 
apology. Despite the absence of direct victims, the writing of an apology is an ever-present and fundamental piece of every reparation contract. The act of apology itself is said to represent one of a number of potential 'keys' which can ultimately unlock the therapeutic potential of restorative justice practice (Doak, 2011), whilst for Braithwaite (2002: 571), the restorative apology, along with true remorse, can be viewed as 'the most powerful form of censure as [it] is offered by the person with the strongest reasons for refusing to vindicate the victim by censuring the injustice'. However, in many of the cases observed, it was clear that direct victims, or victim representatives, did not receive the apology letter as they did not want to become involved in the process at any level. The RJS-based programme manager noted that the exercise represented an act of symbolic reparation (Retzinger \& Scheff, 1996; Tavuchis, 1991) providing a format for the offender to think more about their behaviour, the harm caused by the crime and to whom, and the various ways with which that harm could be repaired.

Similar practical concerns over the management and distribution of apology letters, and the ongoing conflict between rehabilitation and restoration within restorative justice practice generally, have been observed within restorative cautioning practices (Hoyle, Young \& Hill, 2002) and investigations of the English and Welsh Youth Offender Panel (YOP) programmes (Hoyle \& Rosenblatt, 2016; Rosenblatt, 2015). For example, both Gray (2005: 951) and Rosenblatt (2015) found within their respective studies that young offenders were asked to write letters of apology within YOP case deliberations which were never sent to victims. Arguably, whilst this may serve some purpose in forcing offenders to think in greater detail about their behaviour and the harm caused by it, it simply results in an exercise in the 'consequences of offending' and serves to promote the 'responsibilisation' and rehabilitation of the offender over reparation goals (Hoyle \& Rosenblatt, 2016: 37).

Whilst it is important to acknowledge these perceived limitations within panel procedures, reparation panellists have attempted to successfully uphold restorative principles despite faced with these procedural difficulties. In many ways panellists find themselves in a 'catch-22' position when attempting to compensate for a lack of victim participation. Offenders are offered a face-to-face meeting with victim support groups as part of contract agreements and this can compensate for direct victim participation in some way. Regardless of the fact that the victim attends meetings or not, the harm caused by the offending behaviour still has to be addressed within case discourses. In all but three panel cases, observed apologies were offered up within case meetings and by letter. Access to a collection of these letters illustrated that the remorse offered appeared genuine, heartfelt and sincere. Participants regularly directly apologised to panel members in meetings. These were offered up voluntarily and without prompting by panellists, and also appeared to be sincere with one participant crying as he did so.

It is difficult to attempt to quantify the level of genuine remorse illustrated within a written apology. Indeed, whilst some theorists argue that remorse is a necessary and vital requirement of an apology (Braithwaite, 2002; Tauvachis, 1991), others such as Duff (2003: 387) contest that insincere apologies can still 
remain at least partly effective. ${ }^{8}$ Whilst the collective reparative contract terms, if completed successfully, can help panellists and the referring judge to gauge the general level of remorse on offer, practical reality has illustrated that panellists can only hope, through the holding of a reparation panel based on restorative principles, that those apologies contain at least a level of true remorse and genuine regret and help participants to more fully realise the harm caused by the offending behaviour.

Somewhat controversially, especially for those theorists who believe that a process can only be classed as fully restorative if all primary stakeholders are involved directly (McCold, 2004), a lack of victim participation within panel meetings might actually be improving conditions for the meso-community of care and concern to flourish. Reparation panellists have honed efforts to get to the core of the offending behaviour by discussing issues with offenders such as relational problems, a lack of employment opportunities, debt concerns and dependency issues. In doing so, community representatives and community sourced caseworkers have explored community-based support and rehabilitative services without the fear of possible accusations of offender bias witnessed in other jurisdictions wherein restorative conference facilitators limited their potential for support, advice and the promotion of community interests due to a need to remain 'neutral' during case discussions (Gerkin, 2012: 289).

In addition, any lack of a bridging of social capital bonds between offenders and direct victims was compensated for in the relationships between participating offenders and community representative volunteers within the RJC model and between offenders and caseworkers as part of the RJS programme. It has been argued that in a restorative justice process, 'community has three roles, it should have a say in how the victimised community is repaired, it should benefit from this reparation, and it should attempt to reintegrate offenders back into that community as positive, contributing members' (Rosenblatt, 2014: 297). Reparation panels strive to accomplish these communitarian goals in a number of ways. For example, rather than picking from a scripted 'dessert menu' of reparation tasks as observed previously within YOP programmes (Rosenblatt, 2014: 294; Hoyle and Rosenblatt, 2016: 37), although some alcohol and drug rehabilitation visits remain as standard contract tasks, RJC volunteers were creative in the formation of reparative contract tasks.

By way of illustration, during case discussions of an assault charge it emerged that the participant had represented the local county as a footballer. The male volunteer suggested that, as part of his reparation contract, which included letters of apology and financial reparation to a local charity, he could recommend the participant to the manager of the local youth football club so that he could help out with a number of training sessions. Thus, community resources were being drawn upon and relational bonds developed between the offender and the

8 Duff (2003) argues that the demand that the wrongdoer apologise, even if we suspect that his apology will not be sincere, can communicate both to him and to the victim some recognition of the wrong that he did: and that the actual experience of apologising might help to bring him to recognise for himself the effects of the wrongdoing. 
wider community. Within another public order case managed by RJC, the offender told the panel that he was a painter and decorator. The volunteer on this occasion knew the local youth club manager and noted that the club building was in need of refurbishment. Ensuring the panellists that the youth club manager would be in favour, the offender agreed that a number of hours could be included within the reparation contract for painting and repairing the hall. Such examples illustrate the potential for local community members to reap real benefits from the reparative contract. The community around which the offence took place should be a recipient of any reparation agreed by and acquired from the offender and this is even more important within the reparative panel process wherein benefit to direct victims is limited. Further, the offender has an opportunity to illustrate to the panellists, judge and local community members a degree of 'active accountability' representing a 'shift in the public identity of the lawbreaker' and illustrating that the participant is ready to take active responsibility for the offending behaviour and pay back the community in a positive way (Bazemore \& Stinchcomb, 2004: 17).

Within contract negotiations as part of another RJC managed case example, the attending community representative volunteer explained to the participant charged with a public disorder offence that he personally knew the manager of the public house in which the offence took place. He noted that, although not a direct victim as such, the bar manager would be agreeable to a meeting with him in order to apologise for any distress caused. The facilitator remarked that this action, as part of the wider reparation contract, would increase the participant's chances of having the charge struck out of court as judges tended to look favourably on such reparative gestures.

Other observations included a nurse volunteer panellist offering advice about medical problems, a volunteer who worked as a teacher offering educational and academic course advice, and a social worker community representative recommending locally based mental health providers. Thus, unlike criticisms from other programmes surrounding the 'genuine' representative nature of local community volunteers (Willis, 2016: 185), the reparative community representatives were actively involved within the local area, the 'community of place' (McCold, 1998), and were active participants within panel discourses managing social care elements within the 'meso-community of care and concern'. They also played an active and equal role alongside their criminal justice professional counterparts, in forming reparation contracts and recommending community-based, rehabilitative options as part of the 'meso-community of accountability'. Some concerns remain within future case discourses over the embellishing of victimhood and the possible 'responsibilisation' of participants. These concerns can be addressed to some extent by way of a renewed emphasis on increasing victim participation within panel practices even on an indirect level. In addition, a series of more intensive training classes for criminal justice professional and community representative panellists would help to better implement restorative justice principles within panel practices. In doing so, it is hoped that both reintegrative and restorative outcomes can be fully realised for all stakeholders within the 'newly identified meso-community of care, concern and accountability'. 
In conclusion, this study of reparation panel practices and procedures has introduced a novel, theoretical panel-specific meso-community which is a product of the restorative principles, and welfare themed discourses between panel members and each participant offender. It has emerged within the community-led rehabilitative and reintegrative welfare-based elements in reparation contract agreements, as well as the constant emphasis on the need for participants to be fully accountable for their actions and to make amends for the harm caused. These relational meso-bonds between offenders, criminal justice professionals, community representative volunteers and programme employees have resulted in community-led contract agreement strategies which can ultimately increase opportunities for rehabilitation, reintegration and a non-recidivist future. However, panellists can also improve practices by limiting responsibilisation discourses and increasing victim participation within, what is at its core, an offendercentric justice model. If these concerns are successfully addressed, this reparation styled meso-community and the principles engaged within, although specific to the Irish jurisdiction, can be transferred over to other restorative models and improve the respective restorative values and communitarian ethos therein.

\section{References}

Atkinson, P. \& Coffey. A. (2002). Revisiting the relationship between participant observation and interviewing. In. J.F. Gubrium \& J.A. Holstein (eds.), Handbook of interview research (pp. 801-814). London: Sage Publications.

Bazemore, G. (2005). Whom and how do we reintegrate? Finding community in restorative justice. Criminology and Public Policy, 4(1), 131-148.

Bazemore, G. \& Erbe, C. (2004). Reintegration and restorative justice: towards a theory and practice of informal social control and support. In S. Maruna \& R. Immarigeon (eds.), After crime and punishment. Pathways to offender reintegration (pp. 27-56). Cullompton: Willan Publishing.

Bazemore, G. \& Stinchcomb, J. (2004). A civic engagement model of re-entry: involving community through service and restorative justice. Federal Probation, 68(2), 14-24.

Bottoms, A. (2003). Some sociological reflections on restorative justice. In A. Von Hirsch, J. Roberts, A. Bottoms, K. Roach \& M. Schiff (eds.), Restorative justice and criminal justice: competing or reconcilable paradigms? (pp. 79-113). Oxford: Hart Publishing.

Braithwaite, J. (1989). Crime shame and reintegration. Cambridge: Cambridge University Press.

Braithwaite, J. (2002) Setting standards for restorative justice. British Journal of Criminology, 43(2), 563-577.

Braithwaite, J. \& Daly, K. (1995). Masculinities, violence and communitarian control. In T. Newburn \& E.A. Stanko (eds.), Just boys doing business (pp. 189-213). London: Routledge.

Braithwaite, J. \& Mugford, S. (1994). Conditions of successful reintegration ceremonies: dealing with juvenile offenders. British Journal of Criminology, 34(2), 139-171.

Christie, N. (1981). Limits to pain. London: Martin Robinson.

Cohen, S. (1985). Visions of social control. Cambridge: Polity Press.

Daly, K. (2006). The limits of restorative justice. In D. Sullivan \& L. Tifft (eds.), Handbook of restorative justice: a global perspective (pp. 134-145). London: Routledge. 
Daly, K. (2016). What is Restorative Justice? Fresh Answers to a Vexed Question. Victims and Offenders, 11(1), 9-29.

Denzin, N.K. (1989) The Research Act: A Theoretical Introduction to Sociological Methods. New Jersey: Prentice Hall International.

Denzin, N.K. \& Y.S. Lincoln. (1998) Collecting and interpreting qualitative materials. London: Sage Publications.

Department of Justice. (2009). National Commission on restorative justice final report. Dublin: Department of Justice, Equality and Law Reform.

Dhami, M.K. \& Joy, P. (2007). Challenges to establishing volunteer-run, community based restorative justice programs. Contemporary Justice Review: Issues in Criminal, Social and Restorative Justice, 10, 9-22.

Doak, J. (2011). Honing the stone: refining restorative justice as a vehicle for emotional redress. Contemporary Justice Review, 14(4), 439-456.

Duff, R.A. (2003). Restorative punishment and punitive restoration. In G. Johnstone (ed.), A restorative justice reader (pp. 382-397). Cullompton: Willan Publishing.

Etzioni, A. (1994). The spirit of community: the reinvention of American society. New York: Simon and Schuster.

Etzioni, A. (1995). The spirit of community: rights, responsibilities and the communitarian agenda. London: Fontana.

Garland, D. (2001). The culture of control. Oxford: Oxford University Press.

Gerkin, P. (2012). Who owns this conflict? The challenge of community involvement in restorative justice. Contemporary Justice Review: Issues in Criminal, Social and Restorative Justice, 15(3) 277-296.

Giordano, P., Schroeder, R. \& Cernkovich, A. (2007). Emotions and crime over the life course: a neo-Meadian perspective on criminal continuity and change. American Journal of Sociology, 112(6), 1603-1661.

Gray, P. (2005). The politics of risk and young offenders' experiences of social exclusion and restorative justice. British Journal of Criminology, 45(6), 938-957.

Hoyle, C. \& Rosenblatt, F.F. (2016). Looking back to the future: threats to the success of restorative justice in the United Kingdom. Victims \& Offenders, 11(1), 1-20.

Hoyle, C., Young, R. \& Hill, R. (2002) Proceed with caution: an evaluation of the Thames Valley Police Initiative in restorative cautioning. York: Rowntree Foundation.

Kenney, J. S. \& Clairmont, D. (2009). Using the victim role as both sword and shield: the interactional dynamics of restorative justice. Journal of Contemporary Ethnography, 38(3), 279-307.

Leonard, L. \& Kenny, P. (2011.) Measuring the effectiveness of restorative justice practices in the Republic of Ireland through a meta-analysis of functionalist exchange. The Prison Journal, 91(1), 57-80.

Levrant, S., Cullen, F.T., Fulton, B. \& Wozniak, J.F. (1999). Reconsidering restorative justice: the corruption of benevolence revisited? Crime and Delinquency, 45, 3-27.

Maruna, S. (2001). Making good: how ex-convicts reform and rebuild their lives. Washington, DC: American Psychological Association.

Maruna, S. (2016). Desistance and restorative justice: it's now or never. Restorative Justice: An International Journal, 4(3), 289-301.

Maruna, S. \& Ramsden, D. (2004). Living to tell the tale: redemption narratives, shame management and offender rehabilitation. In A. Lieblich, D. McAdams, \& R. Josselson (eds.), Healing plots: the narrative basis of psychotherapy (pp. 129-149). Washington, DC: American Psychological Association.

McAdams, D.P. \& McClean, K.C. (2013). Narrative identity. Current Directions in Psychological Science, 22(3), 233-238. 
McCold, P. (2000). Toward a holistic vision of restorative juvenile justice: a reply to the maximalist model. Contemporary Justice Review 3(4), 357-414.

McCold, P. (2004). What is the role of community in restorative justice theory and practice? In H. Zehr \& B. Toews (eds.), Critical issues in restorative justice (pp. 155-172). New York: Criminal Justice Press.

McCold, P. \& Wachtel, B. (1998). Community is not a place: a new look at community justice initiatives. Contemporary Justice Review, 1(1), 71-85.

McCold, P. \& Wachtel, B. (2003). Community is not a place: a new look at community justice initiatives. In G. Johnstone (ed.), A restorative justice reader (pp. 294-295). Cullompton: Willan Publishing.

McStravick, D. (2015). Behind the restorative veil: an insight into Irish reparation panel practice and theoretical principles. Contemporary Issues in Law, 13(3), 193-215.

Mika, H. \& Zehr, H. (2003). A restorative framework for community justice practice. In K. McEvoy \& T. Newburn (eds.), Criminology, conflict resolution and restorative Justice (pp. 135-145). Basingstoke: Palgrave MacMillan.

Morris, G. \& Morris, A. (1999). Understanding re-offending. Wellington: Institute of Criminology.

Olson, S.M. \& Dzur, A.W. (2004). Revisiting informal justice and democratic professionalism. Law and Society Review, 38(1), 139-176.

O'Mahony, D. \& Doak, J. (2006). The enigma of 'Community' and the exigency of engagement: restorative youth conferencing in Northern Ireland. British Journal of Community Justice, 4(3), 9-24.

Petrich, D.M. (2016). Theorising desistance-promotion in circle processes: the role of community in identity transformation. Restorative Justice: An International Journal 4(3), 388-409.

Petrich, D. \& Morrison, B. (2015). The alternatives to violence project: using positive criminology as a framework for understanding rehabilitation and reintegration. In T. Gavrielides (ed.), Offenders no more: an interdisciplinary restorative justice dialogue (pp. 247-266). Hauppauge: NOVA Science Publishers.

Probation Service (2012). Report on Pilot Expansion of Probation Funded Adult Restorative Justice Projects. Dublin.

Putnam, R. D. (2000). Bowling alone: the collapse and revival of American community. New York: Simon and Schuster.

Retzinger, S. \& Scheff, T. (1996). Strategy for community conferences: emotions and social bonds. In B. Galaway \& J. Hudson (eds.), Restorative justice: international perspectives (pp. 315-336). New York: Criminal Justice Press.

Rodriguez, N. (2005). Restorative justice, communities, and delinquency: whom do we reintegrate? Criminology \& Public Policy, 4(1), 103-130.

Rosenblatt, F.F. (2014). Community involvement in restorative justice: lessons from an English and Welsh case study on youth offender panels. Restorative Justice: An International Journal, 2(3), 280-301.

Rosenblatt, F.F. (2015). The role of community in restorative justice. New York: Routledge.

Rossner, M. (2011). Restorative justice and micro-sociology. In S. Karstedt, I. Loader \& H. Strang (eds.), Emotions, crime and justice (pp. 169-192). Oxford: Hart Publishing.

Rossner, M. (2013). Just emotions: rituals of restorative justice. Oxford: Oxford University Press.

Rossner, M. \& Bruce, J. (2016). Community participation in restorative justice. Rituals, reintegration and quasi-professionals. Victims and Offenders 11(1), 107-125.

Rubin, H. \& Rubin, I. (2012). Qualitative data: the art of hearing data. Thousand Oaks: SAGE Publications. 
Schluter, M. (2003). What is relational justice? In G. Johnstone (ed.), A restorative justice reader (pp. 303-311). Cullompton: Willan Publishing.

Schroeder, R.D., Giordano, P.C. \& Cernkovich, S.A. (2010). Adult-child-parent bonds and life course criminality. Journal of Criminal Justice, 38(4), 562-571.

Sherman, L. (1993). Defiance, deterrence and irrelevance: a theory of the criminal sanction. Journal of Research in Crime and Delinquency, 30(4), 445-473.

Strang, H. (2001). Justice for victims of young offenders: the centrality of emotional harm and restoration. In A. Morris \& G. Maxwell (eds.), Restorative justice for juveniles: conferencing, mediation and circles (pp. 183-193). Oxford: Hart Publishing.

Strang, H. (2004). Is Restorative Justice Imposing its Agenda on Victims? In H. Zehr \& B. Toews (eds.), Critical issues in restorative justice (pp. 95-105). New York: Criminal Justice Press.

Sykes, G. \& Matza, D. (1957). Techniques of neutralisation: a theory of delinquency. American Sociological Review, 22, 664-670.

Tavuchis, Nicholas. (1991). Mea Culpa: A Sociology of Apology and Reconciliation. Stanford: Stanford University Press.

The National Crime Forum. (1998). National Crime Forum Report. Dublin: Institute of Public Administration.

Tyler, T. (1990). Why people obey the law. New Haven: Yale University Press.

Tyler, T.R. \& Huo, Y. (1990). Trust in the law: encouraging public cooperation with the police and the courts. New York: Russell Sage Foundation.

Umbreit, M. (1998). Restorative justice through victim-offender mediation: a multi-site assessment. Western Criminology Review, 1(1). Retrieved from http://www. westerncriminology.org/documents/WCR/v01n1/Umbreit/Umbreit.html (last accessed 31 January 2018).

Umbreit, M.S., Coates, R.B. \& Vos, B. (2004). Restorative justice versus community justice: clarifying a muddle or generating confusion. Contemporary Justice Review, 7, 81-89.

Verity, F. \& King, S. (2008). Responding to intercommunal conflict - what can restorative justice offer? Community Development Journal, 43(4), 470-482.

Walgrave, L. (2002). From community to dominion: in search of social values for restorative justice. In E.G.M. Weitekamp \& H. Kerner (eds.), Restorative justice: theoretical foundations (pp. 71-75). Cullompton: Willan Publishing.

Ward, T. \& Brown, M. (2004). The good lives model and conceptual issues in offender reintegration. Psychology Crime and Law, 10(3), 243-257.

Ward, T. \& Maruna, S. (2007). Rehabilitation: beyond the risk paradigm. London: Routledge.

Willis, R. (2016). Three approaches to community in restorative justice, explored through a young person's experience of a youth offender team in England. Restorative Justice: An International Journal, 4(2), 168-194.

Wood, W.R. \& Suzuki, M. (2016) Four challenges in the future of restorative justice. Victims \& Offenders, 11(1), 149-172.

Woolford, A. (2009). The politics of restorative justice: a critical introduction. Halifax: Fernwood Publishing.

Wright, J.P., Cullen, F.T. \& Miller, J.T. (2001). Family social capital and delinquent involvement. Journal of Criminal Justice, 29(1), 1-9.

Zehr, H. (1990). Changing lenses: a new focus for crime and justice. Scottsdale: Herald Press. 